\title{
THE NANSEN COMMISSION AND THE ROMANIAN PRISONERS OF WAR'S 1 REPATRIATION FROM THE RUSSIAN TERRITORIES
}

\section{Ioana Ecaterina Cazacu}

"Al. I. Cuza" University of Iassy, Faculty of History, E-mail: ioanacazacu@yahoo.com

\section{Acknowledgments}

This paper has been presented at the Second International Conference on Nordic and Baltic Studies in Romania: Black Sea and Baltic Sea Regions: confluences, influences and crosscurrents in the modern and contemporary ages hosted by the Romanian Association for Baltic and Nordic Studies, Târgoviste, May 20-22, 2011. This research for this paper was achieved with the support of the POSDRU/88/1.5/S/47646 project.

\begin{abstract}
:
The end of the Great War was the beginning of a long string of problems requiring immediate solutions, one of the most important of which being the repatriation of former prisoners of war. Given the fact that there were a large number of prisoners as a result of the huge amount of troops engaged in the conflict, we can approximate a number of 6,637,000 prisoners at the end of the war. This situation did not remain without consequences in the international debate. At the Paris Peace Conference, the General Secretariat had organized a Special Committee on all matters relating to prisoners. The lead of the Commission was entrusted to Fridtjof Nansen, explorer, scientist and public figure of the period. However, there were a number of difficulties generated by the absence of Russia from the Peace Conference. This country did not obey any decisions of the Commission, having neither rights, nor duties. To solve the problems, the High Commissioner made use of the prestige given by the League of Nations in order to facilitate the carrying out of his duty, but in reality the effort to repatriate the prisoners was supported by humanitarian agencies and private organizations, for example the International Red Cross. Overall the Mission led by Dr. Nansen managed to repatriate 427,885 prisoners, 19,188 of whom were Romanians.
\end{abstract}

\section{Rezumat:}

Sfârşitul Marelui Război a fost începutul unui şir lung de probleme care necesitau soluții imediate, dintre care unul dintre cele mai importante a fost repatrierea foştilor prizonieri de război. Având în vedere faptul că a existat un număr mare de prizonieri, ca urmare a magnitudinii trupelor angajate $\hat{\imath}$ conflict, putem aproxima un număr de 6.637 .000 de prizonieri la sfârşitul războiului. Această situație nu a rămas fără consecințe in cadrul dezbaterii internaționale şi la 
Conferința de Pace de la Paris, Secretariatul General a organizat un comitet special cu privire la toate aspectele legate de prizonieri. Conducerea Comisiei i-a fost încredințată lui Fridtjof Nansen, explorator, om de ştiință şi figură publică a perioadei. Cu toate acestea, au existat o serie de dificultăți generate de absența Rusiei de la Conferința de Pace. Această tară nu se supunea nici uneia din deciziile Comisiei, neavând nici drepturi, nici obligații. Pentru a rezolva problemele, Innaltul Comisar a făcut uz de prestigiul dat de către Liga Națiunilor pentru a facilita realizarea scopului său, dar, în realitate, efortul de a repatria prizonierii a fost susținut de către agențiile umanitare şi de organizațiile private, de exemplu de Crucea Roşie Internațională. In general, misiunea condusă de dr. Nansen a reuşit să repatrieze 427.885 de prizonieri, dintre care 19.188 au fost români.

Keywords: POWs, Russia, The International Red Cross, The International Relief Credit Commission, Nansen Commission.

The First World War have remained in the collective consciousness as a crucial moment that marked the transition from an age of innocence, "la belle époque," to an age of increasing awareness of the true drama represented by an armed conflict of such scale and barbarity. The overall enthusiasm at the beginning of the war eventually turned into general disappointment. The end the conflagration did only represent the beginning of a long series of problems in need of an immediate solution. Thus, at the international level, urgent solutions were required for thousands of refugees, for the famine haunting many countries, for the populations displaced due to border changes. The problem of war prisoners who were in poor condition in various camps lacking the possibility of returning home stood on top of these.

It should be noted here that the Great War was marked by a novelty as it was for the first time when captivity was carried out to such large a scale as a direct consequence of the size and number of troops engaged in the conflict. Consequently, at the end of the war an estimated number of 6,637 million soldiers were thought to have been taken prisoners. ${ }^{1}$ This generalisation of captivity did not remain without consequences in the international debates, the details of the war prisoners' repatriation were set in the treaty signed with Germany at Versailles, under section "war prisoners and graves," Articles 214-2262. Furthermore, at the Peace Conference in Paris, the Special Commission for all matters relating to the prisoners was organised under the General Secretariat with a view to

\footnotetext{
${ }_{1}^{1}$ François Cochet, Soldats sans armes. La captivité de guerre: une approche culturelle (Paris, 1998).

2 Primary Documents - Treaty of Versailles, Articles 214-226,

http:/ / www.firstworldwar.com/source/versailles214-226.htm (accessed 15 June 2011).
} 
observing the provisions of the Hague Convention with concern to the repatriation of all prisoners at the end of the war ${ }^{3}$. Nonetheless, difficulties have resulted from the absence of Russia at the Peace Conference. It would not comply with the provisions set forth in Paris, having neither rights nor duties. In addition, the Russian territories hosted the largest number of prisoners belonging to the Central Powers and the country was experiencing extremely difficult times due to the civil war and famine.

The news coming from the Russian territories were worrisome to the international authorities. The status of the prisoners on the Russian territory as reported by the International Red Cross was desperate as prisoners did not benefit from financial support from anywhere, and the living conditions were disastrous. The prisoners were housed in wooden barracks, the healthy together with the ill, without food or medicine. The camp at Nova-Mikolaievsk was given as an example, where only 70 prisoners survived out of 1,100.4 Under these circumstances, it was decided that a specialised committee be organised to deal with the repatriation of former prisoners. The leadership of this commission was entrusted to Fridtjof Nansen, an explorer, a scientist and a relevant public figure at the time, whose fame came from the fascination exercised by his North Pole expeditions, advertised in widely circulated newspapers.

It is important to note from the beginning that this article does not follow the many-faceted work of the Nansen Commission, but we are particularly concerned with the relationships between this organisation and Romanians, as individuals who benefited from aid provided by the Commission, and between the Commission and the Romanian State. 5 Moreover, it is also relevant that prisoners of Romanian ethnic origin on the Russian territory were former soldiers of the Austro-Hungarian Empire army, from the Romanian provinces formerly belonging to the empire, who, once Romania entered the war, preferred captivity rather than fighting against their kin.

It was estimated that in Russia there would have been, in the beginning, some 1.25 million prisoners belonging to the Central Powers, of which more than half have died in the chaos caused by the civil war, and some others were repatriated after the Treaty of Brest-Litovsk. There were

3 Cornel Țuă, Prizonieri români din armata austro-ungară internați în Rusia. Problemele repatrierii, doctoral thesis (Iaşi, 2006), 232.

4 Vasilica Sîrbu, Premiile Nobel pentru pace în perioada interbelică (1918-1939), doctoral thesis (Iaşi, 2010), 101.

${ }^{5}$ A recent English-language article on this topic, Silviu Miloiu, "The Baltic escape from hell. The Nansen Office and the Romanian POWs (1919-1921)." Valahian Journal of Historical Studies 15 (2011): 65-82. 
also some 330,000 German civilians who lived in the Russian territories and had been deported to Siberia at the outbreak of the First World War. Upon Fridtjof Nansen's taking over the mission, there seemed to be a further half a million prisoners on the vast Russian territory, who were facing the risk, at any moment, to die from hunger, cold, disease, or hard labour they were subjected to. On the other hand, in Germany there were about a million Russian prisoners, who were not allowed to return to their country from the beginning as the Allies wanted to train troops to fight against the Bolsheviks. The original plan was abandoned and the Russian prisoners were allowed to return to the country. ${ }^{6}$

The general auspices the Commission were to operate under were as unfavourable as possible. To the Westerners' reluctance to recognize the Bolshevik regime, the Allied blockade and their intervention on Russian territory were added. Nevertheless, the Norwegian explorer, forming his own organisation based in Berlin, Nansen Help, brought the two sides to the negotiating table and despite the difficulties posed by transportation and the Soviet authorities' continuing suspicions succeeded in reaching a compromise. Moreover, to assess the situation as close to reality, Nansen visited Russia, where he met Alexander Eyduk, who was responsible for sending foreigners to the western border, and Nansen's organisation was to take them from there. The meeting proved beneficial and a considerable number of prisoners were repatriated via the Baltic Sea.

The High Commissioner used the prestige imposed by the League of Nations to facilitate carrying out its purpose, but, in reality, the true effort to return the prisoners was made by humanitarian agencies and private organisations. Among such organisation, the International Red Cross played an outstanding role, owing to whose effort camps for refugees and prisoners was organized, food was procured and part of the transportation costs for repatriation were financed.7 In fact, the International Red Cross had been involved in solving the prisoners' issue ever since 1919, had already established contacts and sent people to Russia.

Consequently, in May 1920, in a telegram addressed to the Minister of War, the International Red Cross announced that it had agreed to provide repatriation from Russia via Estonia and Finland, of all prisoners of war, irrespective of nationality. Moreover, the German Government had consented to take the necessary steps to organize concentration and transport points from the Russian border to the Austrian border. In

\footnotetext{
${ }^{6}$ Michael R. Marrus, The Unwanted - Europeean Refugees from the First World War through the Cold War, with a new Foreword by Aristide R. Zolberg (Philadelphia :Temple University Press, 2002), 87.

7 Ibid., 88.
} 
contrast, the Red Cross promised the German government to refund all amounts spent for the prisoners' support in the country. The Romanian Government was notified that it was necessary, for the repatriation of Romanian subjects, to make a deposit of 500,000 German marks in the account of the International Red Cross in Berlin, money needed for the prisoners' transport from the Russian border to the Romanian border. 8 Furthermore, the Romanian authorities were informed that between 10 May and 15 June 1920, the International Red Cross Committee delegates in Narva recorded the arrival of a number of 15,746 prisoners - i.e. 7,853 Russians, 2,731 Germans, 43 Estonians, 3,730 Austrians, 1,608 Hungarians, 17 Italians, 124 Romanians, 27 Croats, 12 Bosnians, 289 Czechs, 5 Serbs, 85 Poles, 52 Ukrainians, 562 Swiss, and 998 of various other nationalities. The same information also reminded of the request made since May for fund clearance and that a reply was expected to be able to assist the Romanian prisoners as well. ${ }^{9}$

To carry out the mission assigned, the High Commissioner would need significant financial resources. From the very beginning, the total costs of the repatriation of the prisoners were estimated at 670,000 pounds sterling. The money was to be received by the International Relief Credit Commission from a group of creditor countries. The most important creditor was Great Britain, which pledged to deliver a $£ 227,000$ fund, followed by Italy and France with $£ 85,000$, the Netherlands with $£ 55,000$, Switzerland with $£ 48,000$, and Sweden, Norway and Denmark with $£ 35,000$ each. These contributions were construed as a loan to countries benefiting from Dr Nansen's repatriation project, as follows: Austria and Hungary were to receive $£ 200,000$ each, while Poland, Romania, Czechoslovakia, and Yugoslavia £70,000 each. 10

Despite this international agreement, the Nansen Commission and its chair considered themselves forced to address the Romanian government a memo, on 11 June 1920, asking to expedite the procedures relating to the withdrawal of the amount required to repatriate Romanian prisoners from the Russian territory. 11 In fact, according to the information

\footnotetext{
8 Arhiva Diplomatica a Ministerului Afacerilor Externe [The Ministry of Foreign Affairs Diplomatic Archive], Problema 71/1914 E.2. Prizonieri 11b, vol. 242, dos. 290, Telegram of the International Red Cross Committee addressed to the Minister of War, 14 May 1920, 27 (hereinafter quoted as A.M.A.E.).

9 Ibid., Memo addressed to the Romanian Minister in Geneva by the International Red Cross, 26.

10 The League of Nations Archive, Refugees Mixed Archival Group, Fonds Nansen 19201924, Box R 1707, doc. 7587, (hereinafter quoted as ALN-Nansen).

11 A.M.A.E., Problema 71/1914 E.2. Prizonieri 11b, F. Nansen's memo to the President of the Ministers' Council, 11 June 1920, 1.
} 
received by Antoine Bibesco, the Romanian chargé d'affaires in London, in Russia there would have been about 14,000 Romanian prisoners, for whose repatriation costs an estimated 70,000 pounds sterling at the most were needed, money that could be accessed by the Romanian government through an application to the International Relief Credit Commission. Nonetheless, it should be noted that at that time Romania was the only country among those included in Dr Nansen's project that had not applied for the withdrawal of the money. ${ }^{2} \mathrm{As}$ there was no reply to the application made early in June, Nansen was forced to send another telegram to the President of the Council with a request to submit the formal application before the Credits Committee by 22 June 1920. The Nansen Commission were to submit a preliminary report by that date with a view to mentioning Romania as well among the states that had met their obligations. ${ }^{13}$ The answer came from the Romanian authorities until 5 July 1920.14

The dialogue between Romania and the institution headed by the High Commissioner continued to be weak. Thus, although the Romanian party had agreed to send a petition to the International Relief Credit Commission with a view to clearing the money, this never happened, so that, on 23 August and 8 September two further notifications were sent to the Romanian government for the clearance of funds provided. The Nansen Commission representatives threatened even to stall the repatriation of Romanian prisoners, but the situation was both complex and complicated, as more than 4,000 Romanian prisoners had already been repatriated at the expense of the Commission ${ }^{15}$ via the Baltic Sea route. At the time, the tension between the two sides had considerably increased. Consequently, Philip Baker expressed his dissatisfaction, in two telegrams of 14 September 1920, with the manner the Romanian government had been managing the situation and described its lack of interest as "monstrous". Moreover, he believed that the time of negotiations and talks was over and that it was time to take action. 16

Despite the pressure from the International Relief Credit Commission and the Nansen Commission, in October the situation was not settled yet, but everyone was aware of the fact that the Romanian prisoners were unstoppable in their desire to leave the Russian territory, as, aiming at

\footnotetext{
12 Ibid., Telegram of Antoine Bibesco to the Ministry of Foreign Affairs of 17 Juny 1920, 14.

13 Ibid., Telegram from Antoine Bibesco, Romania's chargé d'affaires in London, to the Ministry of Foreign Affairs, 23 June 1920,11.

14 ALN-Nansen, Box R 1707, Memo of Antoine Bibesco, Romania's chargé d'affaires in London, to Eric Drummond, of 5 July 1920.

15 Ibid., Philip Baker's telegram to Nicolae Titulescu, September 1920.

16 Ibid., Philip Baker's telegram to Nicolae Titulescu, 14 September 1920.
} 
being repatriated, they could choose a different identity than the Romanian one at any time. The only way the Commission members felt they could persuade the Romanian authorities to submit the petition for the clearance of funds was to threaten them with the situation being reported to the General Assembly of the League of Nations. Had that kind of pressure be ineffective, the money representing the costs of Romanian prisoners' repatriation were to be raised from donations and contributions from the other countries. ${ }^{17}$ However, F. Nansen continued to pressure the Romanian government in order to recover the amounts spent for the repatriation of Romanian prisoners. Accordingly, the Norwegian explorer harshly criticised the Romanian authorities' lack of response. At that time, such authorities had not started the procedures to clear the funds yet, and Nansen considered that Romania manifested a deep disregard at the fate of its subjects. He further threatened to present this situation, which he qualified as delicate and embarrassing, to the General Assembly of the League of Nations ${ }^{18}$. Furthermore, the lack of any reply from the Romanian authorities prompted the High Commissioner to threaten with the exclusion of the Romanian prisoners from the repatriation programme and the demanding of financial compensation for the over 4,500 Romanian prisoners repatriated until 15 September 192019. Nansen's threats were implemented and Eric Drummond, in a letter to the Secretary General of the League of Nations, gave an overview of the negotiations between the Romanians and Nansen Commission ${ }^{20}$. Drummond's reaction was immediate and, in a letter to the President of the Council of Ministers, he demanded immediate settlement of the dispute with the organisation with respect to the prisoners' repatriation. ${ }^{21}$

Following the international pressure, the Romanian Minister of Finance, accompanied by Nicolae Titulescu, conducted discussions with the General Secretary of the League of Nations and promised that Romania would make all necessary arrangements to access the funds. Moreover, the two officials expressed their intention to initiate the due formalities in order to solve the situation as fast as possible and argued that the delay occurred because of some [...] misunderstandings 22 . However, the Romanian side had not submitted the petition by 17 November, and Nansen expressed his dissatisfaction with the fact that, in spite of so much pressure, the

\footnotetext{
17 ALN-Nansen, Box C 1112(8), Philip Baker's telegram to J. H. Gorvin, 16 October 1920.

18 Ibid., F. Nansen's telegram to the Minister of Foreign Affairs, 19 October 1920.

19 ALN-Nansen, Box R 1707, Philip Baker' letter to Nicolae Titulescu, October 1920.

20 Ibid., F. Nansen's letter to Eric Drummond, 19 October 1920.

21 Ibid., Eric Drummond's letter to the President of the Ministers' Council, October 1920.

22 ALN-Nansen, Box. C 1112(8), Philip Baker's telegram to Garvin, 2 November 1920.
} 
Romanian government failed to respond: "I think this means that you do not want your prisoners to be repatriated from Russia" and, consequently, Romania was obliged to explain its conduct before the General Assembly of the League of Nations. Such explanations meant that the Romanian government were to give reasons for their failure to observe the initial promises. Although threatening that the Romanian prisoners' repatriation was no longer part of the plans conducted by the organisation, he would still indicate that the arrival of a large number of Romanians was expected and that Romania was bound to see to their fate. 23

The delayed response of the Romanian authorities was understandable if we were to consider the post-war critical situation in the country as well as the lack of a better organisation and functioning of the state institutions. The issue seems to have been eventually solved by the end of 1920, as the report, submitted to the Council of the League of Nations on 26 February 1921, made no reference as to the dispute mentioned above. 24

The repatriation of prisoners from the Russian territory was carried out via three routes: the Baltic Sea, the Black Sea, and from Vladivostok. We further present the results achieved by the Nansen Commission during the first year of operations, as shown in the report submitted to the General Assembly of the League of Nations. Thus, by that time, 280,000 prisoners, of which 10,500 Romanians, had been repatriated via the Baltic Sea. The representatives of the Nansen Commission were satisfied with the result, should the transport difficulties due to the winter be taken into account. Moreover, the Narva and Bjorko harbours being blocked by ice, rail transport was mostly resorted to. In addition, in order to facilitate the repatriation proceedings, a point of concentration was set up at Baltischport since November, which, together with Riga, operated regularly and satisfactorily until the end of the project. ${ }^{25}$

Considering the achievements, Nansen appreciated the usefulness of railroad to the repatriation of prisoners, although this solution had a series of drawbacks such as the disruption within a number of regions in the Baltic or the difficulty of obtaining permits for trains to cross through the Polish Corridor. Therefore, on 17 January 1921, representatives of the German, Soviet, Polish, Latvian and Lithuanian government held a meeting in Riga, which ended with signing an agreement. Railway transportation

\footnotetext{
23 A.M.A.E., Problema 71/1914 E.2. Prizonieri 11b, F. Nansen's telegram to the Romanian Minister of Foreign Affairs, 46.

24 Ibid., Nansen Commission's Report on the 1920 activity, presented in Geneva on 26 February 1921, 64.

25 Ibid., 64-65.
} 
from Russia to other countries was expected to be conducted more easily. Moreover, the Latvian, Lithuanian, and Polish governments had already approved of the trains carrying prisoners to transit these countries. 26

Another route used to bring prisoners from the Russian territory was via the Black Sea. According to the report, due to the disorganisation and chaos reigning in the Russian provinces, it was extremely difficult to estimate the number of prisoners. For this reason, in December 1920, Dr Nansen sent a special mission to the International Red Cross to examine the situation. Before the mission left, an agreement had been reached with the Soviets, whereby prisoners concentrated in the Turkistan area were to be transported to Moscow by rail, wherefrom the Commission was to take over and see to their repatriation via the Baltic Sea route. ${ }^{27}$ The plan worked and some 5,000 prisoners followed this path, although 2,000 remained stranded in Turkistan.

The Red Cross mission extended its activities in the Don, Kuban, Terek, and Ciscaucasia areas, but, due the total disruption of rail transport, it was impossible to conduct repatriation procedures in the abovementioned regions similarly to those in Turkistan. In addition, attention was drawn on the fact that a large number of prisoners, especially Austrian and Hungarian nationals, enlisted various revolutionary armies, which made it even more difficult to estimate the exact number of prisoners. 28 However, it was estimated that around 15,000 prisoners were be repatriated from this area. Moreover, the mission aimed at gathering the prisoners and sending them to Novorossiysk. It was further stated that some 2,000 prisoners were to board at Novorossiysk ${ }^{29}$ harbour in March 1921.

According to Dr Nansen's information, an estimated 15,000 prisoners were to be evacuated via Vladivostok. The American Repatriation Committee made available over one million dollars for the High Commissioner to achieve this objective. ${ }^{30}$ In addition, five ships were already contracted by the U.S. Committee, four of them having carried prisoners from Vladivostok to Trieste since the end of 1920, and the fifth was due to leave on 15 March 1921.31 Thus, the SS Scharnhorst set ashore

\footnotetext{
26 Ibid., 65.

27 Ibid., 66.

28 Ibid.

${ }^{29}$ Ibid., 66-67.

30 The American Committee represented various humanitarian organisations in the USA, the most important of which were the American Red Cross, the Commission for Hungarian population's assistance, the Commission for Austrian war prisoners' assistance, the Federal Council, the National Catholic War Council, etc. (Ibid., 67.)

31 Ibid.
} 
2,200 people on 5 October 1920, the Mainan 2,000 people on 26 October 1920, the Steigerwald 1,176 people on 15 November, and the Frankfurt ${ }^{32} 1,661$ people on 25 November, whereas the Pierre-Benoit was due to leave with 1,800 people on 15 March. At the end of 1920, there were still 7,500 people, of which 1,200 were Romanians 33 , in Vladivostok. The latest news coming from Vladivostok, on 19 January 1921, showed that, after the departure of said vessels and of a number of vessels contracted by various countries, independently from the League of Nations, there remained 3,600 prisoners in various camps in the Vladivostok area, and an additional number of around 3,000 prisoners spread throughout Siberia. Overall, approximately 6,000 people were to be repatriated from this region, and the costs incurred by transport were estimated at least 150,000 pounds sterling. 34

Although Nansen received assurances, when the mission agreed to repatriate prisoners of war, that the financial problems were solved, things turned out to be much more complicated and creditor countries started to impose conditions. Thus, Britain deposited half the amount promised, i.e. $£ 113,000$, and conditioned the payment of the balance on the imbursement of the amounts due by the other countries. In order to clear the amounts, the French government also set two conditions 35 that were promptly met by the Commission; hence, the cash promised by the French, i.e. $£ 15,000$, as well as the amount of $£ 100,000$ in products, were expected to be cleared. The Netherlands also conditioned the disbursement of the second amount of money on the clearance of the money promised by the other countries. In October 1920, Italy sent a letter to the International Committee for Assistance Credits, announcing that it was impossible to transfer the $£ 85,000$ promised, since it had already committed to support financially the prisoners' repatriation from the Italian territory. Nansen found himself trapped in an awkward position, as Italy's clearance of the amounts was a prerequisite for the transfer of the money promised by England and The Netherlands. Later on, the two countries agreed to clear funds if the International Committee for Assistance and Credit could secure the amount of 85,000 pounds sterling. Under the circumstances, Dr Nansen called on

\footnotetext{
32 The SSs Steigerwald and Frankfurt also transported 2,750 Russians from Germany to Vladivostok at the expense of the German state, Ibid., 68.

33 Of which 968 Romanians were embarked on the SS Kayku-Maru ever since 25 November 1920, to reach Trieste. The ship was chartered by the German Red Cross from the Japanese authorities and the costs incurred were covered by the Romanian state, in the Iaşi County Direction of National Archives, Victor Cădere Fund, File 19, 35.

34 A.M.A.E., Problema 71/1914 E.2. Prizonieri 11b, Nansen Commission's Report on the 1920 activity, presented in Geneva on 26 February 1921, 68.

35 Both requirements, i.e. the evacuation of all the French prisoners from Russia and settling the dispute between the Russian authorities and the Austrian ones, were met. (Ibid., 71).
} 
the governments of Canada, Spain, Japan, Chile, Brazil, and Argentina. Unfortunately, Japan, Canada, and Spain gave a negative answer to the request so that collecting the amount of 85,000 pounds sterling became impossible. The financial situation became thus extremely difficult: on the one hand, half of the funds promised in the beginning had not yet been cleared and, on the other hand, the repatriation of prisoners remained a matter that could not be postponed. 36

These are broadly the coordinates of the activities conducted by the Nansen Commission by the end of 1920. Given the critical situation in Russia, the Commission carried on with the same determination to solve the prisoners' issue in the shortest time possible. Thus, the last transport to leave Vladivostok for Trieste under the patronage of the League of Nations was the steamer Peiho at the end of March. The ship had 1,333 passengers on board, of which 103 Romanian prisoners. The Red Cross delegate boarded the ship as well. ${ }^{37}$ However, despite the efforts of the Commission, the situation in this region was far from being resolved. The leader of the consular corps in Vladivostok described the critical status of a number of refugees in a memo sent in November 1921. Due to the critical circumstances in the Russian territories, e.g. famine, civil war, etc., these refugees had been compelled to leave their homes and lead a miserable existence; 478 of them were Romanians (i.e. 191 men and 287 women and children), and there was no one to see to their fate. 38

The joint action of the League of Nations High Commission and of the International Red Cross to repatriate war prisoners' from Russia officially went into liquidation on 31 December 1921. Consequently, these bodies were to see to the repatriation of prisoners until 15 March 1922 at the latest. After this deadline, the interested countries were to see themselves to the fate of the prisoners who remained on Russian territory. ${ }^{39}$

The Nansen Commission presented their final report in Geneva on 1 September 1922. On this occasion, the High Commissioner expressed his joy to have completed such a difficult task, even if, as we have mentioned, at the beginning of 1921 there were still a considerable number of prisoners to be repatriated via the Black Sea route. Therefore, in the autumn of 1921, several ships transported prisoners to the port of Trieste. Some 12,000 prisoners and a number of civilians ${ }^{40}$ could be carried via this route. During

\footnotetext{
36 Ibid, 71-73.

37 Ibid, F. Nansen's telegram sent to the Ministry of Foreign Affairs on 13 March 1921, 89.

38 Ibid., Report of the consular corps in Vladivostok, 17 October 1921,134-137.

39 Ibid., Letter sent by Lucien Cramer, The International Red Cross Committee, to the Romanian Minister of Foreign Affairs, 5 January 1922, 99-100.

40 Ibid., Nansen Commission final report presented in Geneva on 1 September 1920, 110.
} 
the winter 1921-1922, a significant number of prisoners were repatriated via the Baltic Sea route, which determined the High Commissioner to extend the operation of this route until the summer of 1922, in order to enable the prisoners who could not travel during winter to leave the Russian territory. Notwithstanding, the activity recorded a considerable decline since spring, which led to the closure of activity in the summer of 1922.41

Below, we present some data on the total number of war prisoners repatriated by the High Commission of the League of Nations with the assistance of the International Red Cross between May 1920 and July 1922.

A. Prisoners repatriated via the Baltic Sea and by railway: Austrians - 16,961, Americans - 7, Armenians - 2, Belgians - 1, British - 20, Bulgarians - 50, Czechoslovaks - 27,961, Danish - 14, Estonians - 11, Germans - 33,903, Greek - 4, Hungarians - 36,097, Japanese - 1, Italians 1,417, Latvians - 11, Lithuanians - 11, Polish - 7,961, Romanians - 18,140, Swedish - 18, Swiss - 1,162, Turks - 113, Ukrainians - 134, Yugoslavs 11,159; a total of $154,388.42$

B. Prisoners repatriated via the Black Sea: Argentineans - 88, Austrians - 630, Belgians - 12, British - 13, Czechoslovaks - 2,048, Estonians - 5, French - 24, Germans - 1,997, Hungarians - 1,475, Italians - 127, Latvians - 61, Poles - 1,746, Romanians - 901, Spanish - 2, Swedish - 5, Swiss - 65, Yugoslavs - 615; a total of 9,785.43

C. Prisoners repatriated from Vladivostok: Austrians - 814, Bulgarians - 1, Czechoslovaks - 1,178, Germans - 57, Hungarians - 2,596, Latvians - 13, Lithuanians - 10, Poles - 874, Romanians - 649, Turks - 19, Yugoslavs - 637; a total of 6,851. ${ }^{4}$

We can add to the data above a considerable number of Russian prisoners repatriated from German camps 45 . Thus, Dr Nansen's mission recorded a total number of 427,886 prisoners repatriated, of which 19,188 were Romanians. 46

Although the Nansen Commission were concerned throughout their mission with raising the funds necessary to the proper functioning of the prisoners' repatriation programme, we find that, owing to the good management of finances, at the end of the mission there was a surplus of money. Moreover, the money spent for the operations was considerably

\footnotetext{
41 Ibid., 110-111.

42 Ibid., 112.

43 Ibid., 112 - 113.

44 Ibid., 113.

45 From Constantinople, there were 2,406 Russians repatriated via the Baltic Sea and by rail some 241,703 (Ibid., 113).

46 Ibid., 118.
} 
less than the amount initially expected. Thus, although the initial estimate for the costs of the prisoners' repatriation was of approximately 670,000 pounds sterling, the total amount spent was only 436,990 pounds sterling, of which the costs for the prisoners' support were $£ 121,962$, costs of transport were $£ 309,365$, and administrative expenses were $32,662 .{ }^{47}$

Table 1: Amounts received from each country

\begin{tabular}{|c|c|c|c|}
\hline Country & Cash & In kind & Total \\
\hline Denmark & 8.750 & 25.792 & 34.542 \\
\hline France & 65.000 & - & 65.000 \\
\hline Great Britain & 113.500 & - & 113.500 \\
\hline Holland & 44.591 & - & 44.591 \\
\hline Norway & 17.500 & 17.515 & 34.729 \\
\hline Sweden & 17.213 & 17.515 & 34.729 \\
\hline Switzerland & 45.641 & - & 45.641 \\
\hline Total & $\mathbf{3 1 2 . 1 9 6}$ & $\mathbf{5 6 . 7 8 7}$ & $\mathbf{3 6 8 . 9 8 4}$ \\
\hline
\end{tabular}

Source: The League of Nations Archive, Refugees Mixed Archival Group, Fonds Nansen 1920-1924 Box R 1709, Nansen Commission Financial Report, 29 September 1923.

Table 2: Donations

\begin{tabular}{|c|c|}
\hline Institutions & Money $(\boldsymbol{(})$ \\
\hline American Red Cross & 112.500 \\
\hline British Red Cross & 500 \\
\hline Chilean Delegation & 200 \\
\hline Swedish Red Cross & 2.834 \\
\hline Total & 116.054 \\
\hline
\end{tabular}

Source: The League of Nations Archive, Refugees Mixed Archival Group, Fonds Nansen 1920-1924 Box R 1709, Nansen Commission Financial Report, 29 September 1923.

Table 3: Repatriation costs for each country

\begin{tabular}{|c|c|}
\hline Country & Money (£) \\
\hline Austria & 44.683 \\
\hline Ungary & 94.097 \\
\hline Poland & 27.581 \\
\hline
\end{tabular}

47 ALN-Nansen, Box R 1709, Nansen Commission Financial Report, 29 September 1923. 


\begin{tabular}{|c|c|}
\hline Czecho-Slovakia & 92.921 \\
\hline Serb Croat Slovene Kingdom & 36.065 \\
\hline Romania & 52.584 \\
\hline Total & 347.935 \\
\hline
\end{tabular}

Source: The League of Nations Archive, Refugees Mixed Archival Group, Fonds Nansen 1920-1924 Box R 1709, Nansen Commission Financial Report, 29 September 1923.

Furthermore, it is worth mentioning that over 5,000 Romanian prisoners and volunteers were repatriated owing to the efforts of the Romanian Military Mission in Siberia led by Victor Cădere, besides the prisoners repatriated by the organisation headed by Fridjof Nansen.

At the end of the mission, the High Commissioner expressed his joy at having been able to complete the mission he had been entrusted with. Moreover, much of the success was owed to his personality, as his diplomatic skills succeeded in winning the confidence of the Bolshevik authorities, facilitating thus the repatriation process. Imposing a manner of action that was to become a model followed in the interwar and post-war periods, the Norwegian explorer, in the two years, helped over 420,000 people, representing over 20 countries, to return to their countries of origin. 


\section{References:}

\section{A. Archives:}

Arhiva Diplomatica a Ministerului Afacerilor Externe [The Ministry of Foreign Affairs Diplomatic Archive]:

- Problema 71/1914 E.2. Prizonieri 11b, vol. 242, dos. 290.

Direcția Județeană a Arhivelor Naționale Istorice Centrale Iaşi [Iaşi County Direction of National Archives]:

- Victor Cădere Fund, File 19. The League of Nations Archive, Refugees Mixed Archival Group, Fonds Nansen 1920-1924, Box R 1707, Box R 1709, Box C 1112(8).

\section{B. Books and articles:}

Cochet, François. Soldats sans armes. La captivité de guerre: une approche culturelle. Paris, $1998 .$.

Tucă, Cornel. Prizonieri români din armata austro-ungară internați în Rusia. Problemele repatrierii. Doctoral thesis. Iaşi, 2006.

Sîrbu, Vasilica. Premiile Nobel pentru pace în perioada interbelică (1918-1939). Doctoral thesis. Iaşi, 2010.

Marrus, Michael R. The Unwanted - Europeean Refugees from the First World War through the Cold War. with a new Foreword by Aristide R. Zolberg. Philadelphia:Temple University Press, 2002.

Miloiu, Silviu. "The Baltic escape from hell. The Nansen Office and the Romanian POWs (1919-1921)." Valahian Journal of Historical Studies 15 (2011): 65-82.

\section{Internet:}

http:/ / www.firstworldwar.com/source/versailles214-226.htm, Primary Documents - Treaty of Versailles, Articles 214-226. 